\title{
Feeder- and serum-free establishment and expansion of human induced pluripotent stem cells
}

\author{
MEHDI TOTONCHI 1,2,\#, ADELEH TAEI 1 ,, ALI SEIFINEJAD ${ }^{1}$, MOHAMMADSHARIF TABEBORDBAR ${ }^{1}$, \\ HASSAN RASSOULI ${ }^{1}$, ALI FARROKHI ${ }^{1}$, HAMID GOURABI ${ }^{2}$, NASSER AGHDAMI ${ }^{1}$, \\ GHASEM HOSSEINI-SALEKDEH ${ }^{1}$, and HOSSEIN BAHARVAND* ${ }^{*}, 1,3$ \\ ${ }^{1}$ Department of Stem Cells and Developmental Biology, Royan Institute for Stem Cell Biology and Technology, \\ ${ }^{2}$ Department of Genetics, Royan Institute for Reproductive Biomedicine and \\ ${ }^{3}$ Department of Developmental Biology, University of Science and Culture, ACECR, Tehran, Iran
}

\begin{abstract}
Although human induced pluripotent stem cells (hiPSCs) hold great promise as a source of differentiated cells for vast therapeutic implications, many obstacles still need to be surmounted before this can become a reality. One obstacle, a robust feeder- and serum-free system to generate and expand hiPSCs in culture is still unavailable. Here, for the first time, we describe a novel establishment and maintenance culture technique that uses human dermal fibroblasts to generate hiPSCs by introducing four factors, KIf4, Oct4, Sox2, and c-Myc under serum- and feeder-independent conditions. We have used a serum replacement product, conditioned medium (CM), or feeder-free medium (FFM) supplemented with high elevated basicfibroblast growth factor in the absence or presence of Matrigel. Our FFM system in the presence of Matrigel enhanced the efficiency of alkaline phosphatase-positive colonies at a frequency at least $\mathbf{1 0 - f o l d ~ g r e a t e r ~ t h a n ~ t h e ~ c o n v e n t i o n a l ~ m e t h o d ~ o n ~ f e e d e r ~ c e l l s . ~ T h e ~ e s t a b l i s h e d ~ h i P S C s ~ a r e ~}$ similar to human embryonic stem cells in many aspects including morphology, passaging, surface and pluripotency markers, normal karyotype, gene expression, ultrastructure, and in vitro differentiation. Such hiPSCs could be useful particularly in the context of in vitro disease modeling, pharmaceutical screening and in cellular replacement therapies once the safety issues have been overcome.
\end{abstract}

KEY WORDS: serum and feeder-free culture condition, derivation, maintenance

\section{Introduction}

Induced pluripotent stem cells (iPSCs) are the product of somatic cell reprogramming into an embryonic-like state. The generation of iPSCs has vast therapeutic implications, particularly in the context of in vitro disease modeling, pharmaceutical screening, and cellular replacement therapies. Moreover, it provides a unique tool to dissect the molecular events that permit the conversion of one cell type to another [for review see (Nishikawa et al., 2008)].

Direct reprogramming of somatic cells to a pluripotent state was accomplished in 2006, when Takahashi and Yamanaka converted adult mouse fibroblasts to iPSCs through ectopic expression of a selected group of transcription factors (i.e. Oct4,
Sox2, KIf4, and c-Myc) (Takahashi and Yamanaka, 2006). Subsequent reports optimized this technique, and direct reprogramming was achieved in human cells (Aasen et al., 2008; Dimos et al., 2008; Ebert et al., 2009; Li et al., 2009; Lowry et al., 2008; Maherali et al., 2008; Nakagawa et al., 2008; Park et al., 2008a; Park et al., 2008b; Takahashi et al., 2007; Yu et al., 2007), providing an invaluable contribution to the field of regenerative medicine. For instance, Hanna and colleagues used a humanized sickle cell anemia mouse model and showed that it is possible to

Abbreviations used in this paper: CM, conditioned medium; ESC, embryonic stem cell; FFM, feeder-free medium; HDF, human dermal fibroblast; hiPSC, human induced pluripotent stem cell.

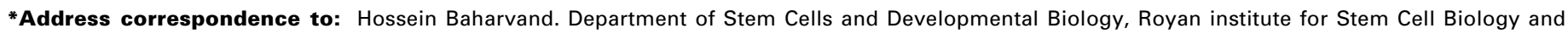
Technology, ACECR, P.O. Box: 19395-4644, Tehran, Iran. Fax: +98-21-2231-0406. e-mail: Baharvand@Royanlnstitute.org

\#Note: These authors equally contributed in this study.
}

Supplementary Material (a video of spontaneously differentiated beating cardiomyocytes) is available at: http://dx.doi.org/10.1387/ijdb.092903mt 
correct the defect by coupling gene targeting and direct reprogramming (Hanna et al., 2007). The differentiated iPSCs could rescue the disease phenotype when transplanted into the donor mice. Similarly, Wernig and colleagues showed that iPSC-derived dopaminergic neurons could alleviate the disease phenotype in a rat model of Parkinson's disease (Wernig et al., 2008b). However, in iPSC generation reports, transduced somatic cells were conventionally reprogrammed and maintained in a culture with feeder cells (i.e. mouse embryonic fibroblasts or MEFs) and/ or mixtures of exogenous factors. However, for future applications involving iPSC-derived cells or tissues, several aspects of human iPSC (hiPSC) biology must be evaluated. For example, the conditions to propagate routine large-scale hiPSCs in an undifferentiated state should be identified; feeder-free cultures qualified for human transplants need to be obtained; and, above all, the long-term stability of such cell lines needs to be determined.

Mouse ESCs can be derived and cultured on gelatin in the absence of feeders and additional growth factors (Ying et al., 2008), and similarly, mouse iPSCs can be derived under feederfree conditions (Stadtfeld et al., 2008a; Wernig et al., 2008a). While defined culture conditions for hESCs have also been established (Amit and Itskovitz-Eldor, 2006; Ellerstrom et al., 2006; Klimanskaya et al., 2005; Ludwig et al., 2006), the derivation of hiPSCs without feeder cells has not yet been reported, though it remains a clinically relevant goal to avoid the use of animal products.

Here, for the first time, we showed that serum and feeder layerfree culture conditions facilitate human somatic cell reprogramming. The resulting hiPSCs expressed pluripotency markers and differentiate into three-germ layer derivatives in vitro. Our system enhanced the efficiency of alkaline positive cells greater than 10 fold from human adult fibroblasts. Our findings greatly simplify the method for induction of pluripotency in human somatic cells and bring it one step closer to clinical applications once the safety issue is overcome.

\section{Results}

\section{Generation of hiPSCs in serum- and feeder-free conditions}

To establish that reprogramming of the human fibroblasts had occurred, and that the putative hiPSCs were pluripotent, we evaluated their similarity to hESCs. At approximately 14 days after infection, some colonies emerged in the infected fibroblast cultures that adopted a tightly packed morphology with refractive edges and three-dimensional growth highly reminiscent of hESC colonies. Cells in these colonies were compact and expressed high nucleus to cytoplasm ratios as well as prominent nucleoli. From $5 \times 10^{4}$ fibroblasts, we observed more hESC-like colonies with ALP activity when $\mathrm{CM}$ was used in comparison with the presence of feeder cells (FC) (Fig. 1). However, the number of ALP-positive colonies increased more when CM or FFM was used. Coating of dishes with Matrigel in both CM and FFM increased significantly the number of ALP-positive colonies (more than 10 fold vs FC and 2 fold vs noncoated dishes, at least $P<0.01$, Fig. 1).

\section{Characterization of established hiPSCs}

Although we initially isolated 20 hiPSC clones from CM and FFM conditions, we focused an in-depth characterization around only five of these clones (two from CM, hiPSC1, hiPSC4, and hiPSC9, and two from FFM, clones hiPSC7 and hiPSC8). All five hiPSC lines exhibited compact colonies with high nucleus to cytoplasm ratio. Moreover, the clones showed strong ALP activity and expressed several hESC-associated antigens (SSEA-3, SSEA-4, Tra-1-60, Tra-1-81, Nanog) (Fig. 2). Additionally, all putative hiPSC lines also maintained a normal karyotype (Fig. 2). The colonies continued to passage after at least 6 months by passaging once a week. The split ratio was 1:3 to 1:6. Colonies were cultured in hESC medium (with KOSR and bFGF) in the absence of feeders and were propagated with enzymatic protocols. The calculated population doubling time of hiPSC was 31.7 \pm 3.9 hours (hiPSC1) hours which is comparable to levels similar to those in hESCs (Baharvand et al., 2006a).

qRT-PCR using primers specific for retroviral transcripts indicated that the hiPSC clones in some, but not all cases, silenced expression of the retroviral transgenes (Fig. 3 A-D). Moreover, whereas expression of the stem cell marker genes Oct4, Nanog, and KIf4 were silent in the human dermal fibroblasts (HDFs), the endogenous loci in the putative hiPSCs were activated to levels similar to those in hESCs (Fig. 3E).

Bisulfite genomic sequencing analyses evaluating the methylation status of cytosine guanine dinucleotides (CpG) in the promoter regions of pluripotent-associated genes, such as Oct4 and NANOG, revealed that they were highly unmethylated; whereas the $\mathrm{CpG}$ dinucleotides of the regions were highly methy-
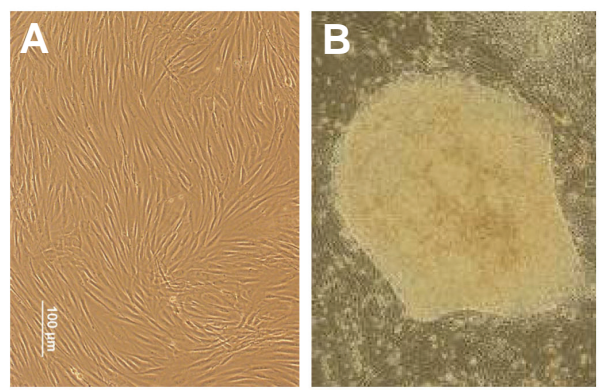

D

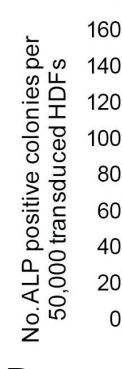

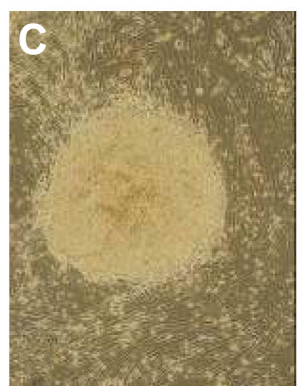

$a, b$
Fig.1. Induction of hiPSCs from adult human dermal fibroblasts (HDF) in serum replacement product and conditioned medium (CM) or feeder-free medium (FFM) supplemented with low and high elevated bFGF in the absence or presence of Matrigel. Phase contrast microscopy of (A) HDF, establishment hiPSC colony at day 20 after infection under CM (B) and (C) FFM. (D) The number of ALP positive colonies under different feeder and serum-free conditions. Feeder cells (FC) used as control group. Results are expressed as the mean and error bars represent the standard deviation (SD). Statistical analysis was performed using one-way ANOVA followed by Tukey's post hoc test.a, $P<0.01$ (3 vs 1 and 2; 5 vs 2 and 4); $b, P<0.001$ (5 vs 1); $c, P<0.05$. 

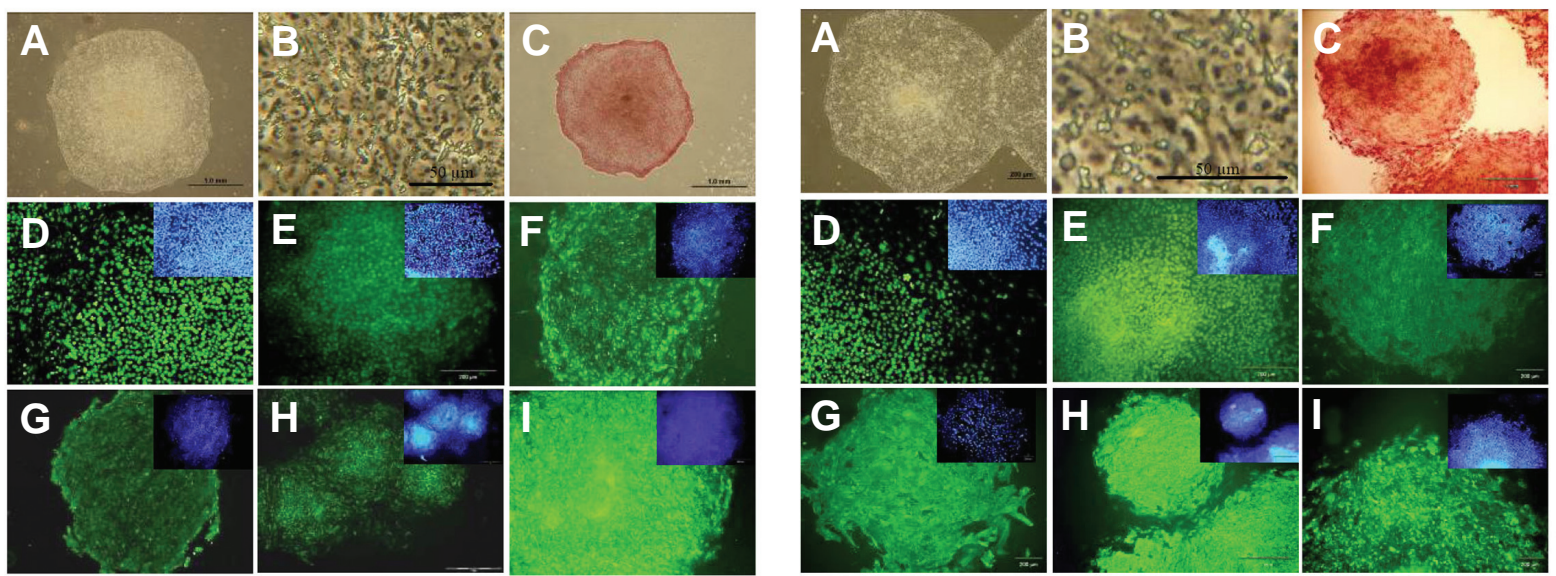

\begin{tabular}{|c|c|}
\hline 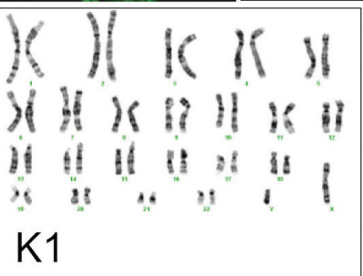 & 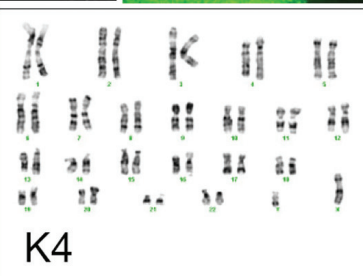 \\
\hline
\end{tabular}
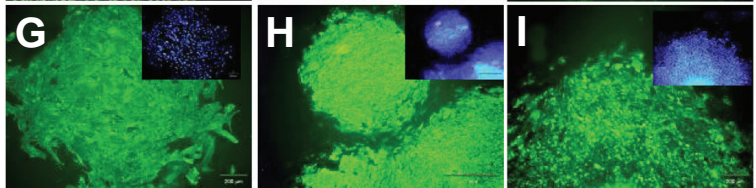

\begin{tabular}{|c|c|}
\hline 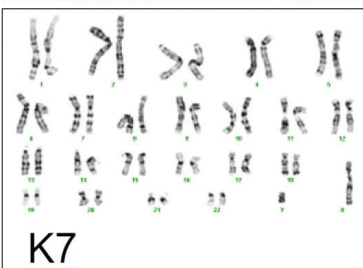 & 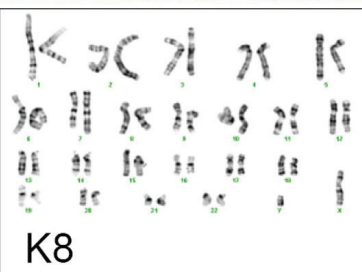 \\
\hline
\end{tabular}

Fig. 2. Characterization of established hiPSCs under CM (left) and FFM (right). (A) Morphology and (B) higher magnification of hiPSCs. Expression of (C) ALP, (D) Nanog, (E) Oct4, (F) SSEA3, (G) SSEA4, (H) TRA-1-60, and (I) TRA-1-81. The karyotype of hiPSC lines (K1, K4, K7, and K8) show normal karyotype in hiPSC clones 1, 4, 7, and 8, respectively. The karyotype of hiPSC1 was normal also (data not shown). The lines are characterized after at least 10 passages. Nuclei were stained with DAPI (blue).

lated in parental HDFs (Fig. 3F). These findings indicate that these promoters are active in hiPSCs.

To demonstrate pluripotency of established hiPSC clones produced under these conditions, they were assayed for their ability to differentiate into lineages representative of the three embryonic germ layers by EB formation. After growing in suspension for 12 days in $\mathrm{hESC}$ medium without bFGF, the EBs were replated in adherent conditions for 8 days. Assaying for expression of genes specific for ectoderm, endoderm, and mesoderm revealed that hiPSC EBs shared a similar ability to up-regulate different lineage markers as the hESC line Royan $\mathrm{H} 5$, demonstrating their pluripotency (Fig.

Fig. 3. Expression of hESC-marker genes in hiPSCs. (A-D) Expression levels of transgenes Oct4 (A), Sox2 (B), KIf4 (C), and c-Myc (D) (relative to GAPDH) were assessed by qRT-PCR. The values from the infected HDF fibroblasts (isolated $5 d$ post-infection, HDF 5d) were set to 1. Uninfected HDF were used as negative controls. The error bar indicates standard deviation (SD). (E) The expression levels of endogenous factors quantified by $q R T-P C R$ and plotted relative to GAPDHexpression. (F) Bisulfite genomic sequencing of the promoter regions of Oct4 and Nanog. Open and closed circles indicate unmethylated and methylated CpGs.
A
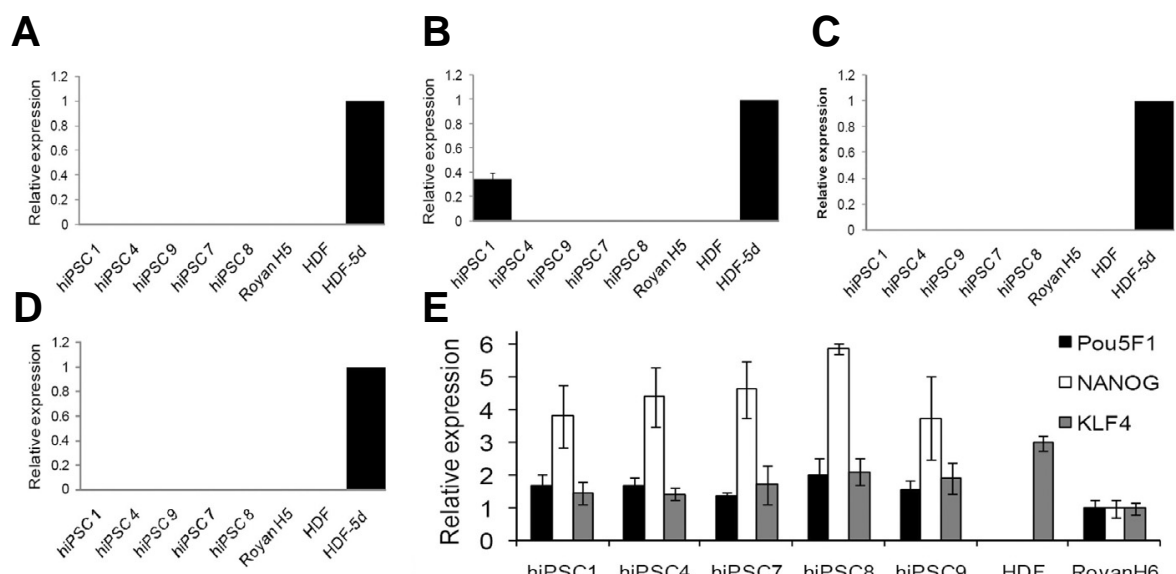

E

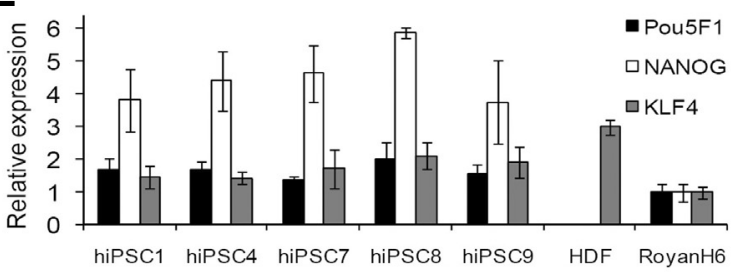

$\mathbf{F}$
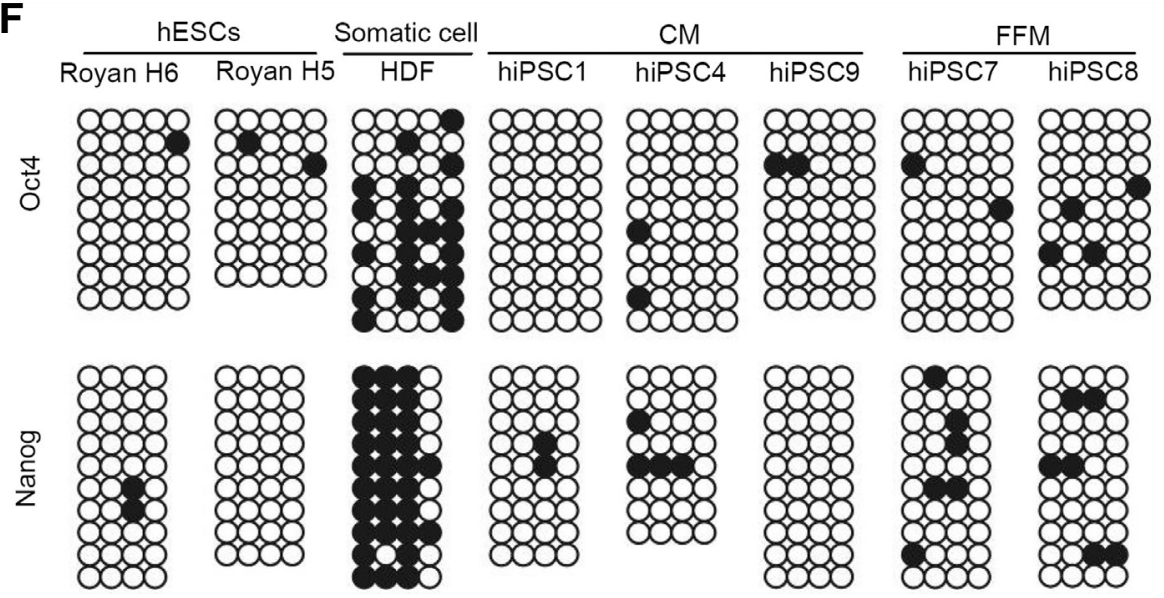
A
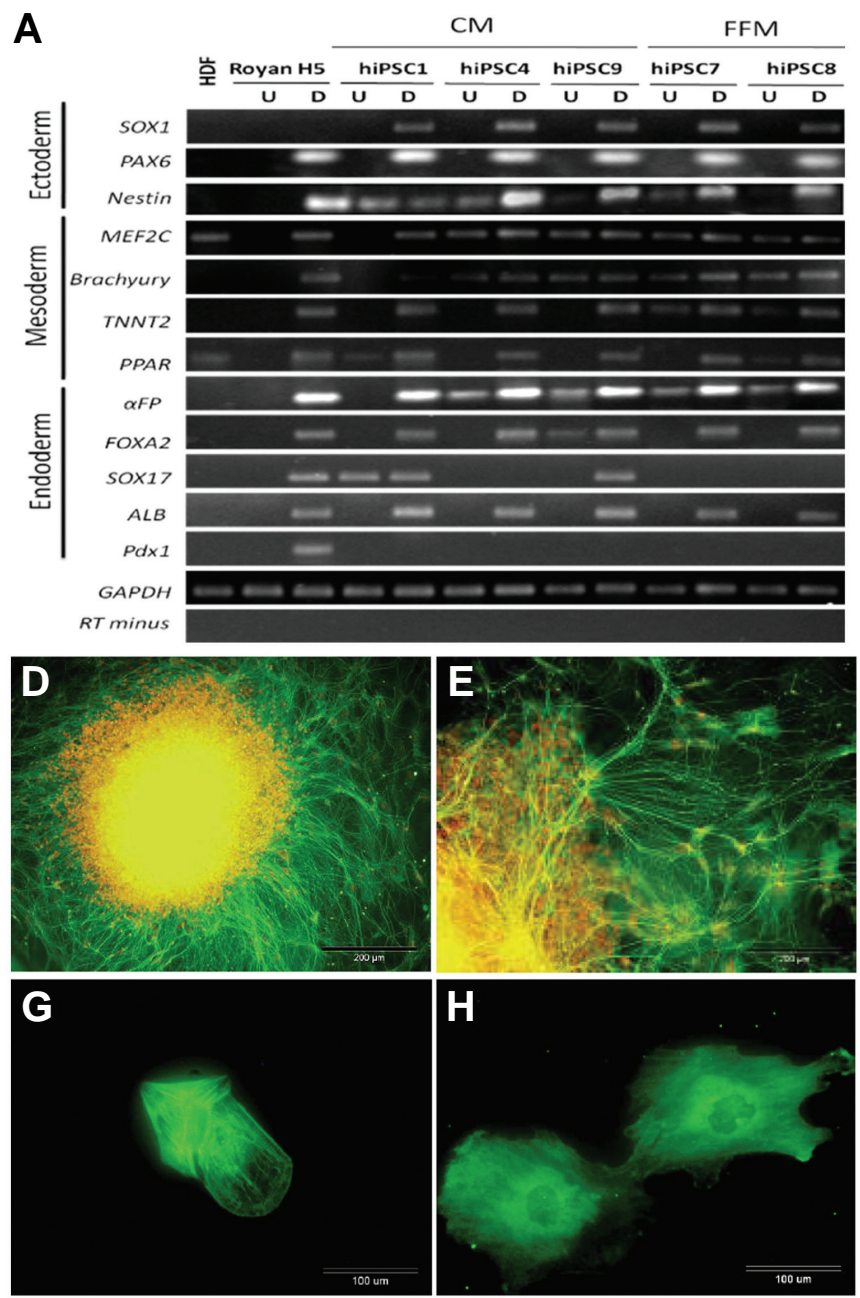

Fig. 4. Differentiation of hiPSCs. (A) $R T-P C R$ analyses of various differentiation markers for the three germ layers by EB-mediated differentiation " $D$ " in comparison with undifferentiated state " $U$ ". Directed differentiation into neural cells in presence of Noggin, RA, and bFGF (B-F). Phase contrast photomicrographs of of neural ectoderm by appearance of rosette structures (B). The neural tube-like structures appeared by more culture (C). The neural tube-like structures isolated mechanically under an inverted microscope and replated without enzymatic treatment on laminin/poly-L-ornithine for $14 \mathrm{~d}$. Immunocytofluorescence of the cells shown in (D) with tubulin III (green) and (E) MAP2 (green) antibodies. Nuclei were stained with propidium iodide (red). (F) Pigmented cells. Beating cardiomyocytes by'EB-mediated differentiation expressed $\alpha$-actinin $(\mathbf{G})$ and Troponin / (H). Sox 17 positive cells (green) after treatment of hiPC1 by Activin A (I). Nuclei were stained with DAPI (blue).

4A). Ectodermal differentiation from spontaneous differentiation of EBs was demonstrated by expression of SOX1, Pax6, and Nestin. Mesodermal differentiation was revealed by expression of MEF2C, Brachyury, TNNT2, and PPAR, whereas endodermal differentiation was highlighted by $\alpha-F P$, FaxA2, Sox17, Alb, and $\mathrm{Pdx} 1$. Some EBs manifest spontaneous beating, evidence of the formation of contractile cardiomyocytes (supplementary data). The data showed that these differentiation markers were essentially absent in undifferentiated hESCs and hiPSCs and strongly induced only after differentiation of the EBs in each condition. Next we examined whether lineage-directed differentiation of hiPSCs could be induced by the reported methods for hESCs. Upon induction of differentiation by retinoic acid (RA), bFGF, and noggin, known to strongly induce neural differentiation in adher-
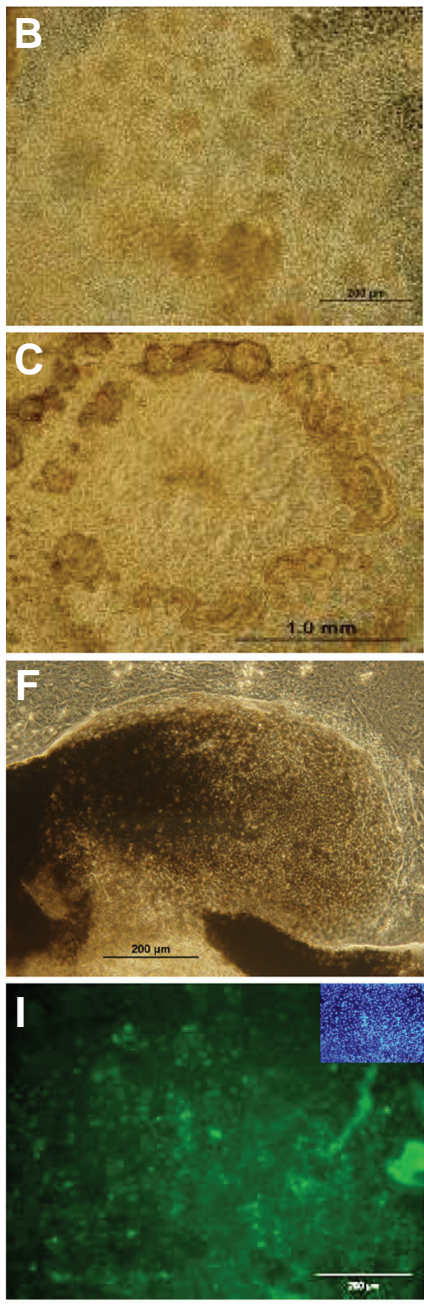

ent conditions, dramatically induced both rosette and neural-tube-like structure formation and neural generation (Fig. 4 B-F). Immunostaining further demonstrated that the differentiated cells strongly expressed tubulin III (Fig. 4D) and MAP2 (Fig. 4E). The beating cells expressed $\alpha$-actinin (Fig. 4G) and Troponin I (Fig. 4H). Moreover, treatment of the cells by Activin A induced strongly sox 17 , an endodermal marker (Fig. 4I). Only pluripotent cells would have the ability to up-regulate markers of all three embryonic germ layers providing strong evidence for the pluripotency of hiPSC clones.

\section{Ultrastructure of undifferentiated hiPSCs and hESCs}

Observation by SEM showed that the hiPSCs were closely opposed to each other; however, there were clefts of extracellular space between adjacent cells in a colony. On the exterior cell surface of the hiPSCs numerous microvilli could be seen. Microvilli were rare in some cells whilst in others the microvilli were abundant (Fig. $5 \mathrm{~A}, \mathrm{~B}$ ). Under the TEM (Fig. 5 C-J for hiPSC1 and $5 \mathrm{~K}$-L for Royan H5, hESCs), some of the microvilli were in contact with other cells and some projected into the free space. Interdigitating processes were also seen between the cells in the colonies. Pinocytotic vesicles and associated coated pits could be seen along areas of the peripheral cytoplasm and plasma membranes (Fig. 5D). Desmosome-junctions and gap junctions were also seen between cells (Fig. $5 \mathrm{D}-\mathrm{F}$ and $\mathrm{K}, \mathrm{M}$ ). In some cells, prominent cortical bands of microfilaments running the length parallel to the cell surface were observed (Fig. 5G). The cytoplasm to nucleus ratio was low and lipid droplets were present in the cytoplasm. Centrioles were detected (Fig. $5 \mathrm{H}$ and L). The Golgi apparatus occupied an area close to the nucleus with flattened cisternae. Long profiles of rough endoplasmic reticulum with studded ribosomes were seen. The cytoplasm was quite rich in free ribosomes/polysomes. Lysosomes were rarely seen. Mitochondria were round to ovoid with cristae arranged in an arch-like manner or parallel to the mitochondrial wall. The cristae of the mitochondria appeared to be both tubular and lamellar in structure but were nearly always enlarged, angular and translucent, thus giving the intracristal spaces a swollen appearance. The translucence of the intracristal spaces was made more prominent by their juxtaposition with the mitochondrial matrix that was often more electron dense than the surrounding cytoplasm and particularly regular in its granularity. 
The cells had large spherical to elongated nuclei with one to three dense nucleoli in which fibrillar centers containing fibrillar and granular components were observed. The appearance of nuclei was euchromatin. The nuclear envelope had two membranes pierced by numerous pores.

\section{Discussion}

In this study, we showed that hiPSCs can be generated from adult HDF by retroviral transduction of four of Yamanaka's factors by using serum and feeder-free culture conditions. We analyzed colonies selected for hESC-like morphology from HDF for expression of ALP, Nanog, Oct4, SSEA3, SSEA4, Tra-1-81, and Tra-160 , all markers shared with hESCs (Adewumi et al., 2007). We also analyzed gene expression by qRT-PCR analysis, and noted that, expression of Oct4, Nanog, and Klf4 was markedly increased over the respective fibroblast population. In hiPSCs, retroviral expression of human Oct4, Sox2, c-Myc, and Klf4 is silenced during hiPSC generation and complemented by reactivation of expression from the endogenous gene loci (Hotta and Ellis, 2008; Park et al., 2008b; Takahashi et al., 2007). Repro-
hiPSC1
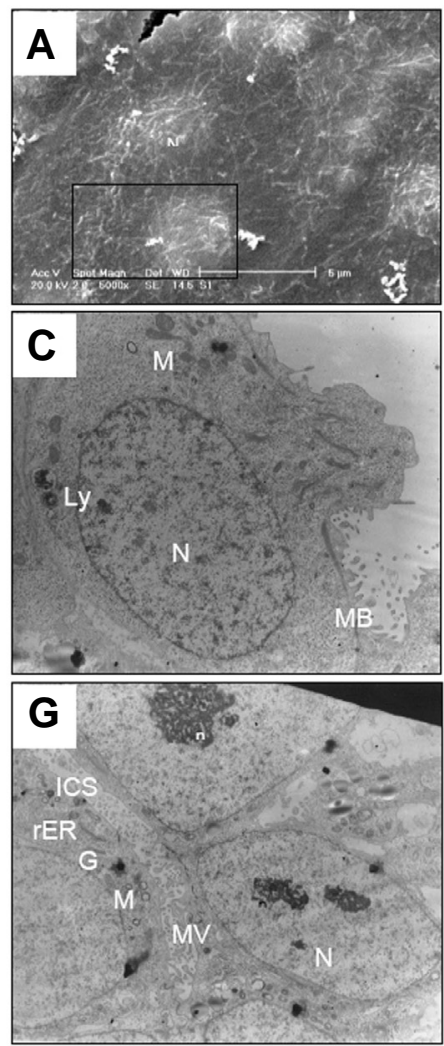
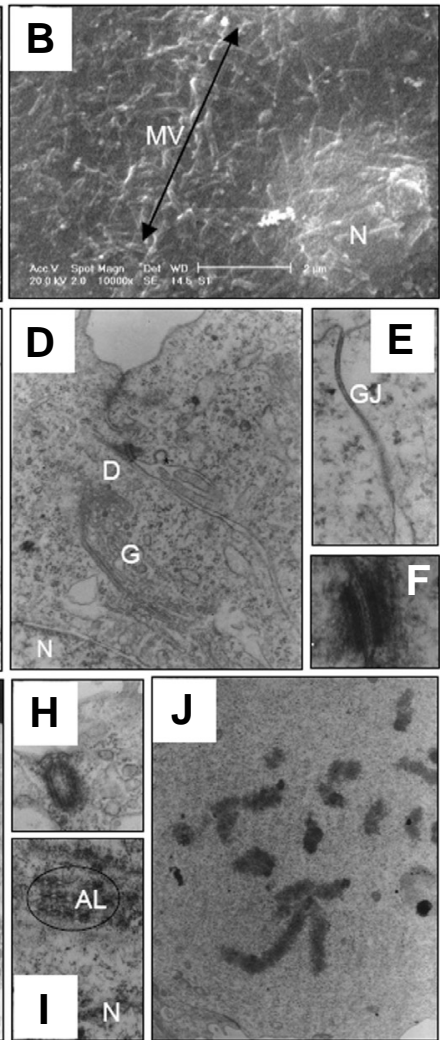

gramming of somatic cells is accompanied by demethylation of promoters of critical pluripotency genes (Cowan etal., 2005; Tada et al., 2001). Therefore, we performed bisulphite sequencing to determine the extent of methylation at the OCT4 and Nanog gene promoters for HDFs and their reprogrammed hESC-like derivatives. As expected, hESC were predominantly demethylated at the OCT4 and Nanog promoters and established hESC-like lines revealed prominent demethylation, also. In contrast, the HDFs showed prominent methylation at these loci, consistent with transcriptional silencing in these differentiated cells. These data are consistent with epigenetic remodelling of the OCT4 and Nanog promoters after retroviral infection, culture and selection for colonies with an hESC-like morphology. Then, to evaluate the pluripotency of established hiPSCs, we used spontaneous differentiation by EB formation and directed differentiation. RT-PCR and immunofluorescence staining of differentiated cells showed marker gene expression for all three embryonic germ layers. Whether the hiPSC clones exhibit pluripotency in vivoby teratoma formation and direct transplantation of in vitro differentiated cells into appropriate tissues to demonstrate their functional significance remains to be explored. Nonetheless, there are controver-
Royan H5

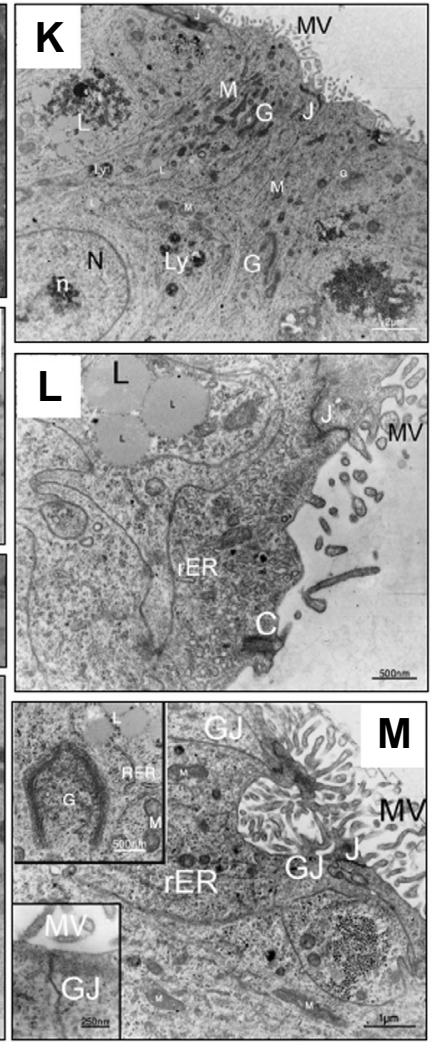

Fig. 5. Ultrastructure of undifferentiated hiPSCs and hESCs. (A) Scanning electron microscopy of hiPSC1. (B) Magnified area of insert in (A). Interdigitation of microvilli (MV) and extension between hiPSCs (arrow). The swelling shows the nucleus (N) site. Transmission electron micrographs of hiPSC1 (C-J) and hESCs (Royan H5) (K-M). The ultrastructure characteristics of hiPSCs are comparable to hESCs. microvilli $(M V)$, lipid droplets (L), mitochondria (M), lysosomes (Ly), Golgi complex (G), rough ER (rER), reticulated nucleoli (n) in nuclei (N) and centriole (C). AL, annulate lamellae; ICS, intercellular space; J, junctional complex; $M B$, microfilament bundle; $D$, desmosome; GJ, gap junction. ${ }^{*}$ show pinocytosis by coated pit formation. Magnifications; (C) 12000x; (E) 50000x; (F) 85000; (J) 4400x; (H,N,D) 20000x. sies on the standards (in vitro differentiation or in vivoteratoma formation) for hiPSC pluripotency (Daley et al., 2009; Ellis et al., 2009; Lowry et al., 2008; Maherali and Hochedlinger, 2008).

Moreover, we compared ultrastructural features of hiPSCs and hESCs. No major structural differences could be seen in hESCs and hiPSCs, presumably indicating that all of the cells were at the same undifferentiated state. These characteristics are comparable to the mouse ESCs (Baharvand and Matthaei, 2003) and hESCs (Sathananthan et al., 2002) which reported before. ALP-positive colonies from $5 \times 10^{4}$ transduced HDFs in FC condition. The basis for the low efficiency is poorly understood but may reflect a multitude of factors such as the starting cell type, cell-cycle status, cell culture conditions, and the ability to undergo replication, variability in factor reactivation, other stochastic events (Hochedlinger and Plath, 2009) and/or small portion of cells expressing all four of the factors at the right levels (Takahashi et al., 2007). Moreover, the low frequency suggests that rare tissue stem/progenitor cells that coexisted in the fibroblast cultures might have given rise to the iPSCs. Previous reports
We obtained approximately 10 
have demonstrated the presence of several types of stem cells in adult dermis with the various differentiation potential, multipotency (Bartsch et al., 2005; Shi and Cheng, 2004; Toma et al., 2001; Toma et al., 2005) or pluripotency (Chen et al., 2007).

Coating of dishes with Matrigel in both CM and FFM increased the number of ALP-positive colonies (more than 10 fold vs FC and 2 fold vs non-coated dishes). Therefore, the passage of transduced human somatic cells on new feeder cells is not necessary as performing conventionally (Aasen et al., 2008; Dimos et al., 2008; Ebert et al., 2009; Li et al., 2009; Lowry et al., 2008; Maherali et al., 2008; Nakagawa et al., 2008; Park et al., 2008a; Park et al., 2008b; Takahashi et al., 2007; Yu et al., 2007). Matrigel is a complex mixture of mouse sarcoma origin that contains extracellular molecules, such as laminin, collagen IV, heparin sulfate and proteoglycan (Kleinman et al., 1986). Deciphering of the mechanism by which the CM or FFM increase colonies remains elusive.

Our study opens a simple and more efficient avenue to generate patient and disease-specific hiPSCs and simple scaleup culture of hiPSCs for our understanding of self-renewal, differentiation, drug screening, toxicology, disease mechanisms and the pathogenesis of cancer.

As ESC conditions are sufficient to obtain iPSCs from most cell types, it is speculated that conditions used to facilitate ESC derivation may also enhance iPSC derivation. For instance, the use of knockout serum replacement instead of fetal bovine serum greatly facilitates mouse ESC derivation (Cheng et al., 2004) and it is reported to improve the reprogramming of mouse fibroblasts (Blelloch et al., 2007). The use of knockout serum replacement provides an alternative culture condition for the reprogramming of various cell types for which standard serum is unsuitable. An important point to note, however, is that the use of undefined media components such as serum introduces batch-to-batch variability and may not elicit reproducible effects. Thus, it is important to screen individual batches for ESC supportive capacity.

Feeder-free derivation and expansion of hiPSCs in chemically defined medium, according to GMP quality requirements, would be the optimal way. Matrigel contains components of non-human origin thus limiting its possibility for use in culturing these cells for clinical purposes. To replace Matrigel with

TABLE 1

PRIMERS AND REACTION CONDITIONS USED IN CONVENTIONAL RT-PCR, QRT-PCR AND BISULFITE GENOMIC SEQUENCING ANALYSES

\begin{tabular}{|c|c|c|c|c|c|}
\hline Gene Symbol & Sequences 5'--- 3' & Size (bp) & Annealing Temp. $\left({ }^{\circ} \mathrm{C}\right)$ & Accession number & Application \\
\hline Oct4 & $\begin{array}{l}\text { TCTATTTGGGAAGGTATTCAGC } \\
\text { ATTGTTGTCAGCTTCCTCCA }\end{array}$ & 124 & 61 & NM_002701.4 & qPCR \\
\hline Nanog & $\begin{array}{l}\text { CAGCTACAAACAGGTGAAGAC } \\
\text { TGGTGGTAGGAAGAGTAAAGG }\end{array}$ & 147 & 61 & NM_024865.2 & qPCR \\
\hline KIf4 & $\begin{array}{l}\text { ATTACCAAGAGCTCATGCCA } \\
\text { CCTTGAGATGGGAACTCTTTG }\end{array}$ & 152 & 61 & NM_004235.3 & qPCR \\
\hline GAPDH & $\begin{array}{l}\text { CTCATTTCCTGGTATGACAACGA } \\
\text { CTTCCTCTTGTGCTCTTGCT }\end{array}$ & 121 & 61 & NM_002046.3 & qPCR \\
\hline hOct-S944 & CCCCAGGGCCCCATTTTGGTACC & & 60 & & Transgene RT-PCR \\
\hline hSox-S691 & GGCACCCCTGGCATGGCTCTTGGCTC & & 60 & & Transgene RT-PCR \\
\hline hKIf4-S1128 & ACGATCGTGGCCCCGGAAAAGGACC & & 60 & & Transgene RT-PCR \\
\hline hMyc-S1011 & CAACAACCGAAAATGCACCAGCCCCAG & & 60 & & Transgene RT-PCR \\
\hline pMXs-AS3200 & TTATCGTCGACCACTGTGCTGCTG & & 60 & & Transgene RT-PCR \\
\hline met-Oct4 & $\begin{array}{l}\text { GGATGTTATTAAGATGAAGATAGTGG } \\
\text { CCTAAACTCCCCTTCAAAATCTATT }\end{array}$ & 415 & 58 & & Methylation analysis \\
\hline met-Nanog & $\begin{array}{l}\text { TTAATTTATTGGGATTATAGGGGTG } \\
\text { AAACCTAAAAACAAACCCAACAAC }\end{array}$ & 171 & 55 & & Methylation analysis \\
\hline$\alpha \boldsymbol{F P}$ & $\begin{array}{l}\text { GCAGCCAAAGTGAAGAGGGAAGA } \\
\text { GTCATAGCGAGCAGCCCAAAGAAG }\end{array}$ & 217 & 69 & NM_001134 & RT-PCR \\
\hline Faxa2 & $\begin{array}{l}\text { CCACCACCAACCCCACAAAATG } \\
\text { TGCAACACCGTCTCCCCAAAGT }\end{array}$ & 293 & 60 & NM_021784 & RT-PCR \\
\hline Sox 1 & $\begin{array}{l}\text { CAATGCGGGGAGGAGAAGTC } \\
\text { CTCCTCTGGACCAAACTGTG }\end{array}$ & 466 & 60 & NM_005986 & RT-PCR \\
\hline Pax6 & $\begin{array}{l}\text { CAGCTCGGTGGTGTCTTTG } \\
\text { AGTCGCTACTCTCGGTTTA }\end{array}$ & 254 & 60 & NM_000280 & RT-PCR \\
\hline Nestin & $\begin{array}{l}\text { CTCTGACCTGTCAGAAGAAT } \\
\text { CCCACTTTCTTCCTCATCTG }\end{array}$ & 171 & 58 & NM_006617.1 & RT-PCR \\
\hline Sox17 & $\begin{array}{l}\text { CGGTATATTACTGCAACTAT } \\
\text { GGATTTCCTTAGCTCCTCCA }\end{array}$ & 104 & 60 & NM-022454.3 & RT-PCR \\
\hline$A / b$ & $\begin{array}{l}\text { CTGCTTGAATGTGCTGATGACAG } \\
\text { GGCATAGCATTCATGAGGATCTG }\end{array}$ & 365 & 65 & NM_000477.4 & RT-PCR \\
\hline Mef2c & $\begin{array}{l}\text { ACACCTACATAACATGCCACC } \\
\text { ATCATGTTGCCCATCCTTCAG }\end{array}$ & 364 & 60 & NM_002397 & RT-PCR \\
\hline Brachyury & $\begin{array}{l}\text { AATCCTCATCCTCAGTTTGG } \\
\text { GTCAGAATAGGTTGGAGAATTG }\end{array}$ & 140 & 60 & NM_003181.2 & RT-PCR \\
\hline Tnnt2 & $\begin{array}{l}\text { ATTCTGGCTGAGAGGAGGAAG } \\
\text { AAGGAGGCCAGGCTCTATTTC }\end{array}$ & 250 & 65 & NM_000364 & RT-PCR \\
\hline$P d x 1$ & $\begin{array}{l}\text { TGAAGTCTACCAAAGCTCACG } \\
\text { GAACTCCTTCTCCAGCTCTAG }\end{array}$ & 130 & 60 & NM_000209.3 & RT-PCR \\
\hline Ppar & $\begin{array}{l}\text { CTAAAGAGCCTGCGAAAG } \\
\text { TGTCTGTCTCCGTCTTCTTG }\end{array}$ & 330 & 60 & NM_005037 & RT-PCR \\
\hline
\end{tabular}


alternatives; several research groups have used laminin (Beattie et al., 2005; Genbacev et al., 2005; Xu et al., 2001), fibronectin (Amit et al., 2004), and human serum coating (Stojkovic et al., 2005) as replacement of feeder cells in hESC cultures. These more-defined coating matrices also have problems with batchto-batch variance, which could partially explain unsuccessful attempts to use these materials for long-term pluripotent stem cell cultures. More recently, using chemically defined xenofree culture medium and a combination, Harb et al., (Harb et al., 2008) reported a novel culture system combining a single synthetic matrix (poly-D-Lysin), defined medium, mTeSR which is identical to the total animal-free medium, TeSR, except for the use of bovine serum albumin (Lu et al., 2006) and the ROCK inhibitor fully warranted hESC self-renewal independent of animal-derived matrices. An optimal solution for the xeno-problem of Matrigel, KOSR, and GMP quality grade of hiPSCs would be to use defined ECMs or purified human matrix components and defined serum replacement containing purified human or human recombinant components.

Nonetheless, there are several issues that need to be addressed before iPSCs could find broader clinical applications. For example, viral systems have been criticized for their integration into the genome, as genomic insertion has been shown to alter gene function (Fehse et al., 2002), and the reactivation of viral transgene in iPSC-derived chimeric mice has been involved in tumorigenesis. Takahashi et al., found that each hiPSC clone which produced by retroviral vectors contained three to six retroviral integrations for each factor. Thus, each clone had more than 20 retroviral integration sites in total, which may increase the risk of tumorigenesis (Takahashi et al., 2007). Therefore, the use of integrating viruses for iPSC induction has been considered as major obstacle in the pursuit of clinically relevant applications. More recently, several groups successfully generated iPSCs using non-integrative approaches such as vector transfection and transposon gene delivery systems"(Kaji et al., 2009; Okita et al., 2008; Stadtfeld et al., 2008b; Woltjen et al., 2009). More recently, Zhou et al., (Zhou et al., 2009) demonstrated that mouse fibroblasts can be fully reprogrammed into iPSCs by direct delivery of recombinant reprogramming proteins. This protein transduction method represents a significant advance in generating iPSCs and effectively eliminates any risk of modifying the target cell genome by exogenous genetic sequences, which are associated with all previous iPSC methods, and consequently offers a method for generating safer hiPSCs. Our hiPSC generation and maintenance conditions along with overcoming the safety issue of hiPSCs, may bring us one step closer towards developing both the quantity and quality of hiPSCs for regenerative medicine.

\section{Materials and Methods}

\section{Human fibroblast and Plat-A culture}

Under human research subject and stem cell protocols as approved by the institutional review boards, we recruited a healthy 40 -year-old Iranian male to donate a skin biopsy to be used in reprogramming studies and the production of pluripotent stem cell lines. The dermal fibroblasts were isolated as previously described (Chen et al., 2007) by $0.1 \%$ collagenase I (Sigma, C0130). Induction of HDFs within 4-10 passages was performed.
HDFs and Plat-A cells were maintained in FP medium containing Dulbecco's modified Eagle's medium (DMEM; Gibco, 12800-116), $10 \%$ fetal bovine serum (FBS, Gibco), 100 units $/ \mathrm{ml}$ penicillin and 100 $\mu \mathrm{g} / \mathrm{ml}$ streptomycin (Gibco, 15070-063).

\section{Generation of hiPSCs from adult HDFs}

Plat-A packaging cells (Cellbiolab, RV-102) were plated at $6 \times 10^{6}$ cells per $100 \mathrm{~mm}$ dish and incubated overnight. In a separate method, each plasmid was transfected into separate dishes of Plat-A cells. One day later, the cells were transfected with retroviral vector (encoding Oct4, Sox2, Klf4 and c-Myc) using Fugene 6 transfection reagent (Roche, 1815075). Twenty four hours after transfection, the medium was collected as the first virus-containing supernatant and replaced with a new FP medium, which was collected twenty-four hours later as the second viruscontaining supernatant. The virus-containing supernatants were filtered through a $0.45 \mu \mathrm{m}$ pore-size filter and supplemented with $6 \mu \mathrm{g} / \mathrm{ml}$ polybrene (Sigma, H9268). Equal amounts of virus-containing supernatants containing each of the four retroviruses were mixed before transduction, transferred to the fibroblast dish and incubated overnight.

Approximately $80 \times 10^{3}$ fibroblasts per well of a 6 -well plate were transduced twice over 48 hours (renewed daily). They were cultured for three days in FP medium, and then on day five, the transduced cells were passaged by trypsinization in the absence of feeder cells on Matrigel (Sigma, E1270, 1:30) coated or noncoated dishes $\left(5 \times 10^{4}\right.$ cells per $60 \mathrm{~mm}$ dish) in FP medium. Coating with Matrigel was performed at $37^{\circ} \mathrm{C}$ for 2 hours in an incubator. The unbound Matrigel was aspirated off. At day 6 , the FP medium was replaced with (i) MEF conditioned hESC-supportive medium (CM) supplemented with $100 \mathrm{ng} / \mathrm{ml}$ basic-fibroblast growth factor (bFGF, Royan Institute), (ii) serum and feeder layer free-culture medium (FFM) or solely hESC medium supplemented with $100 \mathrm{ng} / \mathrm{ml}$ bFGF. In another experiment, replated fibroblasts were cultured on MEFs with hESC medium supplemented with $4 \mathrm{ng} / \mathrm{ml}$ bFGF as the conventional protocol (control group). The medium was changed every other day.

hESC medium contained DMEM/F12 medium (Gibco, 21331-020) supplemented with $20 \%$ knock-out serum replacement (KOSR, Gibco, 10828-028), 2 mM L-glutamine (Gibco, 25030-024), 0.1 mM $\beta$-mercaptoethanol (Sigma; M7522), 1\% nonessential amino acids (Gibco, 11140035), $100 \mathrm{units} / \mathrm{ml}$ penicillin, $100 \mu \mathrm{g} / \mathrm{ml}$ streptomycin (Gibco, 15070-063), and insulin-transferrin-selenite (ITS, Gibco, 41400-045). Conditioned medium was prepared by overnight incubation of $\mathrm{hESC}$ medium with a confluent MEF feeder layer from NMRI strain which was inactivated by mitomycin C (Sigma, M0503).

Approximately two weeks later, a small number of colonies with hESC morphology (Fig. $1 \mathrm{~B}$ and $\mathrm{C}$ ) could be identified. Twenty five to thirty days after transduction, $20 \mathrm{hESC}$-like colonies from CM and $20 \mathrm{hESC}$-like colonies from FFM, were manually expanded by mechanical disaggregation into small clumps without enzymatic digestion. We defined this stage as passage one. In passage one and later hiPSCs were seeded on a Matrigel-coated plate in hESC medium supplemented with $100 \mathrm{ng} / \mathrm{ml}$ bFGF. The medium was changed every other day. Of these colonies, we focused our initial characterization on 3 lines from CM (hiPSC1, hiPSC4, and hiPSC9) and 2 lines from FFM (hiPSC7 and hiPSC8).

For passaging, hiPSCs were washed once with PBS (Gibco, 14287072 ) and then incubated with DMEM/F12 containing (1:1) collagenase IV (0.5 mg/ml, Gibco, 17104-019), dispase (1 mg/ml, Gibco, 17105-041) or only collagenase IV $(1 \mathrm{mg} / \mathrm{ml})$ at $37^{\circ} \mathrm{C}$ for $5-7 \mathrm{~min}$. When colonies at the edge of the dish were dissociating from the bottom, the enzyme was removed and washed with PBS. Cells were collected by gently pipetting.

\section{Karyotype analysis}

For karyotype analysis, the cells were treated with thymidin $(0.66 \mu \mathrm{M}$, Sigma) for 16 hoursat $37^{\circ} \mathrm{C}$ in $5 \% \mathrm{CO} 2$. After washing, the cells were left for 5 hours and then treated with colcemid (Gibco, $0.15 \mu \mathrm{g} / \mathrm{ml}, 30 \mathrm{~min}$ ). Isolated hiPSCs were exposed to $0.075 \mathrm{M} \mathrm{KCl}$ at $37^{\circ} \mathrm{C}$ for $16 \mathrm{~min}$ and then were fixed with ice-cold 3:1 methanol:glacial acetic acid for three times 
and dropped onto pre-cleaned chilled slides. Chromosomes were visualized using standard G-band staining. At least 50 metaphase spreads were screened and ten of them were evaluated for chromosomal rearrangements.

\section{Immunoflourescence and alkaline phosphatase staining}

hiPSCs were fixed in $4 \%$ paraformaldehyde for $20 \mathrm{~min}$, permeabilized with $0.2 \%$ Triton X-100 for 30 min and blocked in $10 \%$ goat serum in PBS for 1 hour. Cells were incubated with primary antibody for 1 hour at $37^{\circ} \mathrm{C}$, washed, and incubated with FITC-conjugated secondary antibodies, antimouse IgM (1:100, Sigma, F9259), anti-rat IgG (1:100, Sigma, F1763) and anti-mouse IgG (1:200, Sigma, F9006) as appropriate for 1 hour at $37^{\circ} \mathrm{C}$.

Primary antibodies were: anti TRA-1-60 (1:100, Chemicon MAB4360), TRA-1-81 (1:100, Chemicon MAB4381), Oct-4 (1:100, Santa Cruz Biotechnology, SC-5279), SSEA-3 (1:100, Chemicon, MAB4303), and SSEA4 (1:100, Chemicon, MAB4304) for undifferentiated hESC determination and anti neuron-specific tubulin-III (1:250, Sigma, T5293), and microtubule-associated protein (MAP2; 1:200, Sigma; M1406) for neural cell detection, anti Sox17 for endodermal differentiation, and anti- $\alpha$-actinin (1:800, Sigma, A7811) and Troponin I (1:250, Chemicon, MAB169) for mesdermal differentiation. Nuclei were counterstained with DAPI (Sigma, D8417) or propidium iodide (PI, Sigma, P4170). The cells were analyzed with a fluorescent microscope (Olympus, Japan).

Alkaline phosphatase (ALP) staining was performed based on manufacturer's recommendations (Sigma, 86R).

\section{RNA isolation and quantitative $R T-P C R$}

Total RNA was isolated using the RNeasy Mini Kit (Qiagen) and treated with DNasel, RNase Free Kit (Fermentas) to remove genomic DNA contamination. Two micrograms of total RNA was used for reverse transcription reaction with the RevertAid First Strand cDNA synthesis kit (Fermentas) and random hexamer primer, according to the manufacturer's instructions. Quantitative PCR reactions were set up in duplicate with the Power SYBR Green Master Mix (Applied Biosystems) and analyzed with the 7500 real-time PCR system (Applied Biosystems). The sequences of primers are presented in Table 1.

\section{Bisulfite sequencing}

Reprogramming of somatic cells was accompanied by demethylation of promoters of critical pluripotency genes (Cowan et al., 2005; Tada et al., 2001). Bisulfite genomic sequencing analyses that evaluated the methylation statuses of $\mathrm{CpG}$ dinucleotides in the promoter regions of Oct4, KIf4, and Nanog revealed that they were highly unmethylated, whereas the $\mathrm{CpG}$ dinucleotides of the regions were highly methylated in parental HDF. The promoter regions of the human Oct4, Klf4, and Nanog genes were amplified by PCR (Freberg et al., 2007) (Table-1). PCR products were subcloned into the InsTAclone PCR Cloning kit (Fermentas). Ten clones of each sample were verified by sequencing with the M13 universal primer and analyzed by BIQ Analyzer software (Bock et al., 2005).

\section{In vitro differentiation}

To demonstrate whether hiPSC clones produced under these conditions are pluripotent, they were assayed for their ability to differentiate into lineages representative of the three embryonic germ layers. By using standard protocols used for hESC differentiation; hiPSC clones 1, 4, 9, 7, and 8 were subjected to the embryoid body (EB) formation assay. For EB formation, hiPSCs were harvested by treating with collagenase IV/ dispase. The clumps of cells (500-1000 cells) were transferred to bacterial or agarose-coated dishes in DMEM/F12 containing 20\% FBS, $2 \mathrm{mM}$ L-glutamine, $0.1 \mathrm{mM} \beta$-mercaptoethanol, $1 \%$ nonessential amino acids, penicillin and streptomycin. The medium was changed every other day. After 12 days as a floating culture EBs were transferred to a $0.1 \%$ gelatincoated plate and cultured in the same medium for another 8 days. hiPSC1 were differentiated to the neural lineage in defined adherent culture by retinoic acid, noggin and bFGF (Baharvand et al., 2007). Moreover, hiPSC1 induced to endodermal lineages by Activin (King et al., 2008).

\section{Electron microscopy processing}

The hiPSC1 and Royan H5 at day 7 of culture was processed for scanning and transmission electron microscopy (SEM and TEM) as previously described (Baharvand etal., 2006b). Briefly, the samples were fixed using $2.5 \%$ glutaraldehyde in $0.1 \mathrm{M}$ PBS $(\mathrm{pH} 7.4)$ for 2 hours. After washing with PBS, samples were postfixed with $1 \%$ osmium tetra oxide for 1.5 hours before being washed again in PBS, dehydrated in an acetone series and then embedded in epoxy resin. After resin polymerization, sections of approximately $50 \mathrm{~nm}$ were cut and double stained with uranyl acetate and lead citrate. Electron micrographs were taken using a Zeiss EM 900 transmission electron microscope (Zeiss, Oberkochen, Germany).

For SEM microscopy, the hiPSC1 were fixed with glutaraldehyde and osmium tetroxide as described above. They were then washed three times in water ( 5 min each) and dehydrated as previously described. The cells were critical point dried, mounted on aluminium stubs and coated with gold using standard techniques. Samples were viewed using a SEM (XL30, Phillips, the Netherlands).

\section{Statistical analysis}

The number of ALP-positive colonies per $50 \times 10^{4}$ was expressed as the mean \pm standard deviation (SD). Statistical analysis was performed using one-way ANOVA followed by Tukey's post hoc test. The mean difference was significant at the $\mathrm{P}<0.05$ level.

\section{Acknowledgement}

We are gratefulto Piriaei, Asgari, Shahbazi, Mollamohammadi, Pakzad for technical support. This study was supported by a grant from Royan Institute.

\section{References}

AASEN, T., RAYA, A., BARRERo, M.J., GARRETA, E., CONSIGLIO, A., GONZALEZ, F., VASSENA, R., BILIC, J., PEKARIK, V., TISCORNIA, G. et al. (2008). Efficient and rapid generation of induced pluripotent stem cells from human keratinocytes. Nat Biotechnol. 26: 1276-1284.

ADEWUMI, O., AFLATOONIAN, B., AHRLUND-RICHTER, L., AMIT, M., ANDREWS, P.W., BEIGHTON, G., BELLO, P.A., BENVENISTY, N., BERRY, L.S., BEVAN, S. et al. (2007). Characterization of human embryonic stem cell lines by the International Stem Cell Initiative. Nat Biotechno/25: 803-816.

AMIT, M. and ITSKOVITZ-ELDOR, J. (2006). Maintenance of human embryonic stem cells in animal serum- and feeder layer-free culture conditions. Methods Mol Bio/331: 105-113.

AMIT, M., SHARIKI, C., MARGULETS, V. and ITSKOVITZ-ELDOR, J. (2004). Feeder layer- and serum-free culture of human embryonic stem cells. Biol Reprod 70: 837-845.

BAHARVAND, H., ASHTIANI, S.K., TAEE, A., MASSUMI, M., VALOJERDI, M.R., YAZDI, P.E., MORADI, S.Z. and FARROKHI, A. (2006a). Generation of new human embryonic stem cell lines with diploid and triploid karyotypes. Dev Growth Differ 48: 117-128.

BAHARVAND, H. and MATTHAEI, K.I. (2003). The ultrastructure of mouse embryonic stem cells. Reprod Biomed Online 7: 330-335.

BAHARVAND, H., MEHRJARDI, N.Z., HATAMI, M., KIANI, S., RAO, M. and HAGHIGHI, M.M. (2007). Neural differentiation from human embryonic stem cells in a defined adherent culture condition. Int J Dev Bio/51: 371-378.

Baharvand, H., PIRYAel, A., ROHANI, R., TAEI, A., HEIDARI, M.H. and HOSSEINI, A. (2006b). Ultrastructural comparison of developing mouse embryonic stem cell- and in vivo-derived cardiomyocytes. Cell Biol Int 30: 800-807.

BARTSCH, G., YOO, J.J., DE COPPI, P., SIDDIQUI, M.M., SCHUCH, G., POHL, H.G., FUHR, J., PERIN, L., SOKER, S. and ATALA, A. (2005). Propagation, expansion, and multilineage differentiation of human somatic stem cells from 
dermal progenitors. Stem Cells Dev 14: 337-348.

BEATTIE, G.M., LOPEZ, A.D., BUCAY, N., HINTON, A., FIRPO, M.T., KING, C.C. and HAYEK, A. (2005). Activin A maintains pluripotency of human embryonic stem cells in the absence of feeder layers. Stem Cel/s 23: 489-495.

BLELLOCH, R., VENERE, M., YEN, J. and RAMALHO-SANTOS, M. (2007). Generation of induced pluripotent stem cells in the absence of drug selection. Cell Stem Cel/ 1: 245-247.

BOCK, C., REITHER, S., MIKESKA, T., PAULSEN, M., WALTER, J. and LENGAUER, T. (2005). BiQ Analyzer: visualization and quality control for DNA methylation data from bisulfite sequencing. Bioinformatics 21: 4067-4068.

CHEN, F.G., ZHANG, W.J., BI, D., LIU, W., WEI, X., CHEN, F.F., ZHU, L., CUI, L. and CAO, Y. (2007). Clonal analysis of nestin(-) vimentin(+) multipotent fibroblasts isolated from human dermis. J Cel/ Sci120: 2875-2883.

CHENG, J., DUTRA, A., TAKESONO, A., GARRETT-BEAL, L. and SCHWARTZBERG, P.L. (2004). Improved generation of C57BL/6J mouse embryonic stem cells in a defined serum-free media. Genesis 39: 100-104.

COWAN, C.A., ATIENZA, J., MELTON, D.A. and EGGAN, K. (2005). Nuclear reprogramming of somatic cells after fusion with human embryonic stem cells. Science 309: 1369-1373.

DALEY, G.Q., LENSCH, M.W., JAENISCH, R., MEISSNER, A., PLATH, K. and YAMANAKA, S. (2009). Broader implications of defining standards for the pluripotency of iPSCs. Cell Stem Cel/4: 200-1; author reply 202.

DIMOS, J.T., RODOLFA, K.T., NIAKAN, K.K., WEISENTHAL, L.M., MITSUMOTO, H., CHUNG, W., CROFT, G.F., SAPHIER, G., LEIBEL, R., GOLAND, R. et al. (2008). Induced pluripotent stem cells generated from patients with ALS can be differentiated into motor neurons. Science 321: 1218-1221.

EBERT, A.D., YU, J., ROSE, F.F., JR., MATTIS, V.B., LORSON, C.L., THOMSON, J.A. and SVENDSEN, C.N. (2009). Induced pluripotent stem cells from a spinal muscular atrophy patient. Nature 457: 277-280.

ELLERSTROM, C., STREHL, R., MOYA, K., ANDERSSON, K., BERGH, C., LUNDIN, K., HYLLNER, J. and SEMB, H. (2006). Derivation of a xeno-free human embryonic stem cell line. Stem Cells 24: 2170-2176.

ELLIS, J., BRUNEAU, B.G., KELLER, G., LEMISCHKA, I.R., NAGY, A., ROSSANT, J., SRIVASTAVA, D., ZANDSTRA, P.W. and STANFORD, W.L. (2009). Alternative induced pluripotent stem cell characterization criteria for in vitro applications. Cell Stem Cel/4: 198-199; author reply 202.

FEHSE, B., KUSTIKOVA, O.S., LI, Z., WAHLERS, A., BOHN, W., BEYER, W.R., CHALMERS, D., TIBERGHIEN, P., KUHLCKE, K., ZANDER, A.R. etal. (2002). A novel 'sort-suicide' fusion gene vector for T cell manipulation. Gene Ther 9 : 1633-1638.

FREBERG, C.T., DAHL, J.A., TIMOSKAINEN, S. and COLLAS, P. (2007). Epigenetic reprogramming of OCT4 and NANOG regulatory regions by embryonal carcinoma cell extract. Mol Biol Cel/18: 1543-1553.

GENBACEV, O., KRTOLICA, A., ZDRAVKOVIC, T., BRUNETTE, E., POWELL, S., NATH, A., CACERES, E., MCMASTER, M., MCDONAGH, S., LI, Y. et al. (2005). Serum-free derivation of human embryonic stem cell lines on human placental fibroblast feeders. Fertil Steril 83: 1517-1529.

HANNA, J., WERNIG, M., MARKOULAKI, S., SUN, C.W., MEISSNER, A., CASSADY, J.P., BEARD, C., BRAMBRINK, T., WU, L.C., TOWNES, T.M. et al. (2007). Treatment of sickle cell anemia mouse model with iPS cells generated from autologous skin. Science 318: 1920-1923.

HARB, N., ARCHER, T.K. and SATO, N. (2008). The Rho-Rock-Myosin signaling axis determines cell-cell integrity of self-renewing pluripotent stem cells. $P L O S$ ONE 3: e3001.

HOCHEDLINGER, K. and PLATH, K. (2009). Epigenetic reprogramming and induced pluripotency. Development 136: 509-523.

HOTTA, A. and ELLIS, J. (2008). Retroviral vector silencing during iPS cell induction: An epigenetic beacon that signals distinct pluripotent states. $J \mathrm{Cell}$ Biochem 105: 940-948.

KAJI, K., NORRBY, K., PACA, A., MILEIKOVSKY, M., MOHSENI, P. and WOLTJEN, K. (2009). Virus-free induction of pluripotency and subsequent excision of reprogramming factors. Nature 458: 771-775.

KING, C.C., BEATTIE, G.M., LOPEZ, A.D. and HAYEK, A. (2008). Generation of definitive endoderm from human embryonic stem cells cultured in feeder layerfree conditions. Regen Med3: 175-180.
KLEINMAN, H.K., MCGARVEY, M.L., HASSELL, J.R., STAR, V.L., CANNON, F.B., LAURIE, G.W. and MARTIN, G.R. (1986). Basement membrane complexes with biological activity. Biochemistry 25: 312-318.

KLIMANSKAYA, I., CHUNG, Y., MEISNER, L., JOHNSON, J., WEST, M.D. and LANZA, R. (2005). Human embryonic stem cells derived without feeder cells. Lancet365: 1636-1641.

LI, W., WEI, W., ZHU, S., ZHU, J., SHI, Y., LIN, T., HAO, E., HAYEK, A., DENG, H. and DING, S. (2009). Generation of rat and human induced pluripotent stem cells by combining genetic reprogramming and chemical inhibitors. Cel/ Stem Cel/4: 16-19.

LOWRY, W.E., RICHTER, L., YACHECHKO, R., PYLE, A.D., TCHIEU, J., SRIDHARAN, R., CLARK, A.T. and PLATH, K. (2008). Generation of human induced pluripotent stem cells from dermal fibroblasts. Proc Nat/Acad Sci USA 105: 2883-2888.

LU, J., HOU R, BOOTH C.J, YANG S.H and SNYDER M. (2006). Defined culture conditions of human embryonic stem cells. Proc Nat/ Acad Sci USA 103: 56885693.

LUDWIG, T.E., LEVENSTEIN, M.E., JONES, J.M., BERGGREN, W.T., MITCHEN, E.R., FRANE, J.L., CRANDALL, L.J., DAIGH, C.A., CONARD, K.R., PIEKARCZYK, M.S. et al. (2006). Derivation of human embryonic stem cells in defined conditions. Nat Biotechno/24: 185-187.

MAHERALI, N., AHFELDT, T., RIGAMONTI, A., UTIKAL, J., COWAN, C. and HOCHEDLINGER, K. (2008). A high-efficiency system for the generation and study of human induced pluripotent stem cells. Cel/ Stem Ce//3: 340-345.

MAHERALI, N. and HOCHEDLINGER, K. (2008). Guidelines and techniques for the generation of induced pluripotent stem cells. Cel/ Stem Cel/3: 595-605.

NAKAGAWA, M., KOYANAGI, M., TANABE, K., TAKAHASHI, K., ICHISAKA, T., AOI, T., OKITA, K., MOCHIDUKI, Y., TAKIZAWA, N. and YAMANAKA, S. (2008). Generation of induced pluripotent stem cells without Myc from mouse and human fibroblasts. Nat Biotechno/26: 101-106.

NISHIKAWA, S., GOLDSTEIN, R.A. and NIERRAS, C.R. (2008). The promise of human induced pluripotent stem cells for research and therapy. Nat Rev Mol Cell Bio/9: 725-729.

OKITA, K., NAKAGAWA, M., HYENJONG, H., ICHISAKA, T. and YAMANAKA, S. (2008). Generation of mouse induced pluripotent stem cells without viral vectors. Science 322: 949-953.

PARK, I.H., ARORA, N., HUO, H., MAHERALI, N., AHFELDT, T., SHIMAMURA, A., LENSCH, M.W., COWAN, C., HOCHEDLINGER, K. and DALEY, G.Q. (2008a). Disease-specific induced pluripotent stem cells. Cel/134: 877-886.

PARK, I.H., ZHAO, R., WEST, J.A., YABUUCHI, A., HUO, H., INCE, T.A., LEROU, P.H., LENSCH, M.W. and DALEY, G.Q. (2008b). Reprogramming of human somatic cells to pluripotency with defined factors. Nature 451: 141-146.

SATHANANTHAN, H., PERA, M. and TROUNSON, A. (2002). The fine structure of human embryonic stem cells. Reprod Biomed Online 4: 56-61.

SHI, C.M. and CHENG, T.M. (2004). Differentiation of dermis-derived multipotent cells into insulin-producing pancreatic cells in vitro. World J Gastroentero/10: 2550-2552.

STADTFELD, M., MAHERALI, N., BREAULT, D.T. and HOCHEDLINGER, K. (2008a). Defining molecular cornerstones during fibroblast to iPS cell reprogramming in mouse. Cell Stem Cel/2: 230-240.

STADTFELD, M., NAGAYA, M., UTIKAL, J., WEIR, G. and HOCHEDLINGER, K. (2008b). Induced pluripotent stem cells generated without viral integration. Science 322: 945-949.

STOJKOVIC, P., LAKO, M., PRZYBORSKI, S., STEWART, R., ARMSTRONG, L., EVANS, J., ZHANG, X. and STOJKOVIC, M. (2005). Human-serum matrix supports undifferentiated growth of human embryonic stem cells. Stem Cel/s23: 895-902.

TADA, M., TAKAHAMA, Y., ABE, K., NAKATSUJI, N. and TADA, T. (2001). Nuclear reprogramming of somatic cells by in vitrohybridization with ES cells. Curr Biol 11: 1553-1558.

TAKAHASHI, K., TANABE, K., OHNUKI, M., NARITA, M., ICHISAKA, T., TOMODA, K. and YAMANAKA, S. (2007). Induction of pluripotent stem cells from adult human fibroblasts by defined factors. Cel/131: 861-872.

TAKAHASHI, K. and YAMANAKA, S. (2006). Induction of pluripotent stem cells from mouse embryonic and adult fibroblast cultures by defined factors. Ce//126: 663-676. 
TOMA, J.G., AKHAVAN, M., FERNANDES, K.J., BARNABE-HEIDER, F., SADIKOT, A., KAPLAN, D.R. and MILLER, F.D. (2001). Isolation of multipotent adult stem cells from the dermis of mammalian skin. Nat Cell Bio/3: 778-784.

TOMA, J.G., MCKENZIE, I.A., BAGLI, D. and MILLER, F.D. (2005). Isolation and characterization of multipotent skin-derived precursors from human skin. Stem Cells 23: 727-737.

WERNIG, M., LENGNER, C.J., HANNA, J., LODATO, M.A., STEINE, E., FOREMAN, R., STAERK, J., MARKOULAKI, S. and JAENISCH, R. (2008a). A druginducible transgenic system for direct reprogramming of multiple somatic cell types. Nat Biotechno/26: 916-924.

WERNIG, M., ZHAO, J.P., PRUSZAK, J., HEDLUND, E., FU, D., SOLDNER, F., BROCCOLI, V., CONSTANTINE-PATON, M., ISACSON, O. and JAENISCH, R. (2008b). Neurons derived from reprogrammed fibroblasts functionally integrate into the fetal brain and improve symptoms of rats with Parkinson's disease. Proc Natl Acad Sci USA 105: 5856-5861.

WOLTJEN, K., MICHAEL, I.P., MOHSENI, P., DESAI, R., MILEIKOVSKY, M.,
HAMALAINEN, R., COWLING, R., WANG, W., LIU, P., GERTSENSTEIN, M. et al. (2009). piggyBac transposition reprograms fibroblasts to induced pluripotent stem cells. Nature 458: 766-770.

XU, C., INOKUMA, M.S., DENHAM, J., GOLDS, K., KUNDU, P., GOLD, J.D. and CARPENTER, M.K. (2001). Feeder-free growth of undifferentiated human embryonic stem cells. Nat Biotechno/19: 971-974.

YING, Q.L., WRAY, J., NICHOLS, J., BATLLE-MORERA, L., DOBLE, B., WOODGETT, J., COHEN, P. and SMITH, A. (2008). The ground state of embryonic stem cell self-renewal. Nature 453: 519-523.

YU, J., VODYANIK, M.A., SMUGA-OTTO, K., ANTOSIEWICZ-BOURGET, J., FRANE, J.L., TIAN, S., NIE, J., JONSDOTTIR, G.A., RUOTTI, V., STEWART, R. et al. (2007). Induced pluripotent stem cell lines derived from human somatic cells. Science 318: 1917-1920.

ZHOU, H., WU, S., JOO, J.Y., ZHU, S., HAN, D.W., LIN, T., TRAUGER, S., BIEN G., YAO, S., ZHU, Y. etal. (2009). Generation of Induced Pluripotent Stem Cells Using Recombinant Proteins. Cell Stem Cell. 4: 381-384.

\section{Further Related Reading, published previously in the Int. J. Dev. Biol.}

See Special Issue Pattern Formation edited by Michael K. Richardson and Cheng-Ming Chuong at: http://www.ijdb.ehu.es/web/contents.php?vol=53\&issue=5-6

\section{Mouse induced pluripotent stem cells}

Eamon Geoghegan and Lucy Byrnes

Int. J. Dev. Biol. (2008) 52: 1015-1022

Pluripotency and differentiation in embryos and stem cells - Pavia, 17-18 January 2008

James A. Adjaye, Anne G. Byskov, Jose B. Cibelli, Ruggero De Maria, Stephen Minger, Maurilio Sampaolesi, Giuseppe Testa, Catherine Verfaillie, Magdalena Zernicka-Goetz, Hans Schöler, Michele Boiani, Nicola Crosetto and Carlo A. Redi Int. J. Dev. Biol. (2008) 52: 801-809

Neural differentiation from human embryonic stem cells in a defined adherent culture condition Hossein Baharvand, Narges-Zare Mehrjardi, Maryam Hatami, Sahar Kiani, Mahendra Rao and Mahdi-Montazer Haghighi Int. J. Dev. Biol. (2007) 51: 371-378

Differentiation of human embryonic stem cells into hepatocytes in 2D and 3D culture systems in vitro

Hossein Baharvand, Seyed M. Hashemi, Saeid Kazemi Ashtiani and Ali Farrokhi

Int. J. Dev. Biol. (2006) 50: 645-652

Common culture conditions for maintenance and cardiomyocyte differentiation of the human embryonic stem cell lines, BG01 and HUES-7

Chris Denning, Cinzia Allegrucci, Helen Priddle, Maria D. Barbadillo-Muñoz, David Anderson, Tim Self, Nigel M. Smith, C. Tony Parkin and Lorraine E. Young

Int. J. Dev. Biol. (2006) 50: 27-37

Expression of regulatory genes for pancreas development during murine embryonic stem cell differentiation

Josué K. Mfopou, Erik Willems, Luc Leyns and Luc Bouwens

Int. J. Dev. Biol. (2005) 49: 915-922

Embryonic stem cells differentiate into insulin-producing cells without selection of nestin-expressing cells

Przemyslaw Blyszczuk, Christian Asbrand, Aldo Rozzo, Gabriela Kania, Luc St-Onge, Marjan Rupnik and Anna M. Wobus

Int. J. Dev. Biol. (2004) 48: 1095-1104
5 yr ISI Impact Factor $(2008)=3.271$

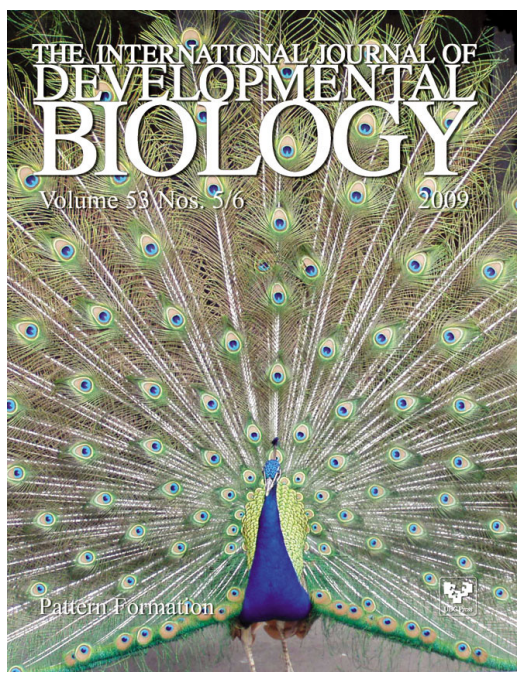

